\title{
Case Report : Nursing Asessment of Patients CKD with Post History Operation Tumormamae
}

\author{
Dewi Ratnasari ${ }^{1}$, Nur Isnaini ${ }^{2}$ \\ ${ }^{1,2}$ Department of Health, Universitas Muhammadiyah Purwokerto, Indonesia
}

\begin{tabular}{|c|c|}
\hline ARTICLE INFO & ABSTRACT \\
\hline Article history: & $\begin{array}{l}\text { Chronic Kidney Disease is a deterioration of kidney function that occurs for } \\
3 \text { months or more. A person with CKD usually does not show any symptoms, }\end{array}$ \\
\hline $\begin{array}{l}\text { DOI: } \\
10.30595 / \text { pshms.v2i.230 } \\
\end{array}$ & $\begin{array}{l}\text { but a person can experience several signs throughout his body such as loss of } \\
\text { appetite, fatigue, water-electrolyte imbalance and so on. Therefore, an } \\
\text { assessment is needed to clarify the medical diagnosis of whether a person }\end{array}$ \\
\hline $\begin{array}{l}\text { Submitted: } \\
\text { December 6, } 2021\end{array}$ & $\begin{array}{l}\text { suffers from CKD or not.To describe the stages of assessment in patients } \\
\text { with an early diagnosis of CKD.The study was conducted in the Darussalam } \\
\text { room, collecting data using auto-anamnesis, direct assessment, and physical } \\
\text { examination. The results of the assessment phase obtained abnormal data on }\end{array}$ \\
\hline Accepted: & the respiratory, digestive, cardiovascular, urinary, musculoskeletal and \\
\hline January 21, 2022 & $\begin{array}{l}\text { integumentary systems. In Mrs.S the whole system almost experiences the } \\
\text { symptoms mentioned in theory when a person has CKD.In accordance with }\end{array}$ \\
\hline Published: & the theory of Mrs. S shows most of the signs and symptoms that appear in \\
\hline January 26, 2022 & $\begin{array}{l}\text { CKD patients. This was also reinforced by supporting examinations which } \\
\text { confirmed that Mrs. S was diagnosed with CKD and was required to undergo } \\
\text { hemodialysis at the hospital. }\end{array}$ \\
\hline
\end{tabular}

Keywords:

Chronic Kidney Disease; This work is licensed under a Creative Commons Attribution 4.0

Nursing Assessment; Vital Sign

International License.

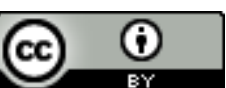

Corresponding Author:

Nur Isnaini,

Department of Health,Muhammadiyah University of Purwokerto,

Soepardjo Rustam Street KM. 7, Banyumas, Indonesia

Email: nurisnaini@ump.ac.id

\section{INTRODUCTION}

Chronic Kidney Disease (CKD) is a problem health global public. CKD happen based on existence damage function kidney or drop (LajuFiltrasi Glomerulus) LFG less than $60 \mathrm{~mL} / \mathrm{min} / 1,73 \mathrm{~m} 2$, LFG considered as a determinant of kidney function. [5]

Kidney disease is a disorder that affects the kidney organs that arise as a result of various factors, usually comes on slowly and is chronic. At first there are no typical symptoms and must be diagnosed through laboratory tests so that the disease is often detected too late.CKD is one of a group of noncommunicable diseases that is a public health problem in Indonesia, According to the Ministry of Health (2019) kidney disease sufferers have increased by 50\% from the previous year and become a serious health problem in the world. In 2018 CKD sufferers in Central Java experienced an increase of $0.06 \%$ in a span of 5 years.

Mamae tumors are mamae disorders that often occur in women. Mamae tumor is a disorder in the growth of normal mamae cells in which abnormal cells arise from normal cells, multiply and infiltrate lymph tissue and blood vessels. [11] There are several treatments for mamae tumors including mastectomy, radiation and chemotherapy.

He increased incidence of acute kidney injury and chronic kidney disease among patients with tumors or cancer is of particular concern especially in areas involving prostate, breast, lung, colorectal, or gynecologic cancers. [20]

An assessment is needed to clarify the medical diagnosis of whether a person has CKD or not. Therefore, the author is interested in knowing the stages of the assessment and the results of the assessment 
in patients who have just been diagnosed with CKD. This study aims to determine the description of the assessment in patients with an initial diagnosis of CKD.

\section{METHOD}

The assessment will be carried out on december 4, 2021 at 09.25 WIB in the Darussalam room by means of an auto-anamnesis, conducting a direct assessment, and conducting a physical examination.

\section{RESULTS AND DISCUSSION}

3.1 Result

In the respiratory system, the results showed that the client experienced shortness of breath, rapid and shallow breathing, RR $24 \mathrm{x} /$ minute with nostril breathing, ronchi sounds were heard.In the cardiovascular system, it was found that the client was anemic, supported also by the presence of low hemoglobin levels and CRT > 3 seconds.

In the gastrointestinal system, there is a decrease in food intake due to nausea, swallowing problems, dry skin turgor, cyanotic mucosa, abdominal enlargement/edema and pain when pressed, the data obtained from the initial BW history: $60 \mathrm{Kg}$, current weight $58 \mathrm{Kg}$ with Height: $155 \mathrm{~cm}$, LILA $16 \mathrm{~cm}$ with BMI value: 24.17. Taste sensing system, the client says the mouth feels bitter, dry mouth, excessive thirst, dirty tongue. In the urinary system the amount of urine is small, the urine is brownish yellow, foamy and receiving furosemide therapy.

In the integumentary system found edema, dry skin, pitting edema>3 seconds, and slightly blackened skin. On examination of the immune system, data showed that the client did not receive complete immunization since childhood, the client did not have any allergies, the client with a postoperative history of mamaetumor, none in the family had the same mamaetumor. On investigation, abnormal results were obtained on examination of levels of urea, creatinine, high leukocytes and hemoglobin, lymphocytes, low MPV.

\subsection{Discussions}

In the respiratory system, the results showed that the client experienced shortness of breath, rapid and shallow breathing, RR $24 \mathrm{x} /$ minute with nostril breathing, this could be due to pulmonary edema caused by a combination of fluid accumulation in the alveoli resulting in progressive gas exchange disturbances. This can be due to pulmonary edema caused by a combination of fluid accumulation (due to increased intravascular pressure or decreased intravascular pressure) in the alveoli, resulting in progressive gas exchange disorders resulting in life-threatening hypoxia. In line with Wong's research in patients with pure CKD events in the respiratory system that usually appear such as pulmonary edema, uremic pleurisy, and pneumonia. [12]

In the cardiovascular system, it was found that the client was anemic, supported also by the presence of low hemoglobin levels and CRT $>3$ seconds. This is due to high levels of urea and creatinine which can inhibit the production of the hormone erythropoietin which results in a decrease in red blood cells. High urea will interfere with the production of the hormone erythropoietin. Erythropoietin affects the production of erythrocytes by stimulating the proliferation, differentiation and erythroid precursor cells, resulting in a decrease in the number of red blood cells or what is known as anemia. [12] In addition CKD patients also appear in the cardiovascular system such as hypertension due to fluid and sodium retention from the activity of the renin-angiotensin-aldosterone system, congestive heart failure and pulmonary edema due to excessive fluid, and pericarditis due to irritation of the pericardial layer by toxins, pruritis, anorexia, nausea, vomiting, hiccups, changes in level of consciousness and inability to concentrate. [2]

In the gastrointestinal system there is a decrease in food intake caused by nausea. This is also due to the increased waste of metabolic waste, namely urea and creatinine circulating in the blood and cannot get out of the body. The increased levels of urea and creatinine can stimulate the production of stomach acid, causing complaints such as stomach ulcers (gastritis), namely nausea, vomiting, heartburn, bloating and no appetite. In line with Ismail's research which states that pure CKD clients can also experience loss of appetite, and experience swallowing disorders. [6] In Tiyasto's research also mentions that CKD patients appear anorexia, nausea, and fomitus which are associated with protein metabolism in the intestine, gastrointestinal bleeding, ulceration, and oral bleeding, breath smells of ammonia. [5]

Taste sensing system, the client says the mouth feels bitter, dry mouth, excessive thirst, this is because the patient is carrying out fluid restrictions which have the aim of avoiding excess fluid.

In the urinary system the amount of urine is small, the urine is brownish yellow, and receiving furosemide therapy. In patients with kidney failure, metabolic waste products from the human blood circulation in the form of water, sodium, potassium, hydrogen, urea and excess creatinine must be removed. As in the kidney function itself, which is to filter waste and excrete it in the form of urine and sweat, in 
patients with kidney failure the kidney function has been damaged so that it requires external assistance in order to excrete these wastes such as the administration of the drug Furosemide given to Mrs. S.

In the integumentary system found edema, dry skin, pitting edema $>3$ seconds, and slightly blackened skin. In patients with kidney failure, the skin tends to look drier than usual. This is due to damage to sweat and oil glands as well as vitamin A metabolism in the body, if this happens, the skin will be at risk of infection and the wound healing process will take longer. In addition the color of the skin can also turn gray due to the accumulation of carotenoids and urine pigments (urochromes). Urine pigment is excreted along with urine, but when it cannot be excreted (urine) then this pigment will accumulate. Apart from these pigments, anemia is also one of the effects that occurs when kidney function decreases which results in a pale face and skin.

On examination of the immune system, data showed that the client did not receive complete immunization since childhood, the client did not have any allergies, the client with a postoperative history of mamaetumor, none in the family had the same mamaetumor.

On investigation, abnormal results were obtained on examination of levels of urea, creatinine, high leukocytes and hemoglobin, lymphocytes, low MPV. Increased blood urea levels due to impaired renal excretory function cause multi-system disorders. This gives rise to systemic symptoms.

\section{CONSLUSIONS AND SUGGESTIONS}

In the respiratory system, the results showed that the client experienced shortness of breath, rapid and shallow breathing, RR $24 \mathrm{x} /$ minute with nostril breathing, this could be due to pulmonary edema caused by a combination of fluid accumulation in the alveoli resulting in progressive gas exchange disturbances. In the cardiovascular system, it was found that the client was anemic, supported also by the presence of low hemoglobin levels and CRT $>3$ seconds. This is due to high levels of urea and creatinine which can inhibit the production of the hormone erythropoietin which results in a decrease in red blood cells. In the gastrointestinal system there is a decrease in food intake caused by nausea. This is also due to the increased waste of metabolic waste, namely urea and creatinine circulating in the blood and cannot get out of the body.

Taste sensing system, the client says the mouth feels bitter, dry mouth, excessive thirst, this is because the patient is carrying out fluid restriction which has the aim of preventing excess fluid from occurring. In the urinary system the amount of urine is small, the urine is brownish yellow, and receiving furosemide therapy. In patients with kidney failure, the kidneys, which function to filter waste substances and excrete them in the form of urine or sweat, have been damaged so that they require external assistance in order to excrete these wastes such as the administration of the drugFurosemide given to Mrs. S. In the integumentary system found edema, dry skin, pitting edema $>3$ seconds, and slightly blackened skin due to accumulation of carotenoids and urine pigments (urochromes).

Urine pigment is excreted along with urine, but when it cannot be excreted (urine) then this pigment will accumulate. On examination of the immune system, data showed that the client did not receive complete immunization since childhood, the client did not have any allergies, the client with a postoperative history of mamaetumor, none in the family had the same mamaetumor. On investigation, abnormal results were obtained on examination of levels of urea, creatinine, high leukocytes and hemoglobin, lymphocytes, low MPV. Increased blood urea levels due to impaired renal excretory function cause multi-system disorders. This gives rise to systemic symptoms. In accordance with the theory, in Mrs.S's patient, multi-system symptoms appear and have similar results with pure CKD

\section{Acknowledgements}

Thank you to Allah SWT, both parents and all comrades in arms who have helped from beginning to end.

\section{REFERENCES}

[1] Cai H, et al. (2018). Protective effects of Salvia miltiorrhiza on adenine-induced chronic renal failure by regulating the metabolic profiling and modulating the NADPH oxidase/ROS/ERK and TGFB/Smadsignaling pathways.(https://www.sciencedirect.com/science/article/pii/S0378874117310243)

[2] Fauzi,Aldy,. Septimar, Zahrah, maulidia,. Wibisono, H.A.Y.G. (2021). Literature Review : Pengaruh Mengunyah Xylitol Terhadap Ph Saliva Dan Rasa Haus Pada Pasien Penyakit Ginjal Kronis Yang Menjalani Hemodialisa Di Rumah Sakit. Jurnal Kesehatan, Vol. 10 No. 1 (2021). Issn 2086-9266 EIssn 2654-587x Doi 10.37048/Kesehatan.V10i1.336

[3] Garini, A. (2018). Kadar Hemoglobin Pada Pasien Gagal Ginjal Kronik Yang Menjalani Hemodialisis. Jurusan Analis Kesehatan Poltekkes Palembang. JPP (Jurnal Kesehatan Poltekkes Palembang) Vol., 13(2), 111-116 
[4] Gilbert, Scott, J., Weiner,Daniel,E.,et all. (2018). National Kidney Foundation's Primer On Kidney Diseases. Canada. Elsevier

[5] Himmelfarb, J., \& Ikizler, T. A. (2019). Chronic kidney disease, Dialysis , and Transplantation - a sompanion to Brenner and rector's the kidney (4rd ed.). https://doi.org/10.1016/B978-0-323-529785.18001-2

[6] Ismail, H. (2018). Asuhan Keperawatan Pada Tn.A Dengan Cronic Kidney Desease (Ckd) Di Ruang Raha Mongkilo RSUD Bahteramas Kendari. Politeknik Kesehatan Kendari

[7] KementrianKesehatan. (2019). Air BagiKesehatan : Upaya Peningkatan Promotif Preventif Bagi Kesehatan Ginjal Di Indonesia. Jakarta. Kementrian Kesehatan RI.

[8] Malyszko, J., Tesarova, P., Capasso, G., \& Capasso, A. (2020). Review The link between kidney disease and cancer: complications and treatment. The Lancet, 396(10246), 277-287. https://doi.org/10.1016/S0140-6736(20)30540-7

[9] Pardede, Chandra,. Darmayanti,Dewi,. Sakurawati, Andi. (2021). Gambaran Hasil Ultrasonografi Urologi Pada Pasien Dengan Klinis Nefrolitiasis. Kieraha Medical Journal Volume 3, Nomor 1, Tahun 2021, E-ISSN:268-5912. https://Ejournal.Unkhair.Ac.Id/Index.Php/Kmj

[10] Pertiwi, Ria A.,Prihati,Dyah R. (2020). Penerapan Slow Deep Breathing Untuk Menurunkan Keletihan Pada Pasien Gagal Ginjal Kronik. Jurnal manajemen asuhan keperawatan vol.4 no.1 hal. 14-19.

[11] Pradesya. (2015). Hubungan Gagal Ginjal Kronik Dengan Edema Paru Ditinjau Dari Gambaran Radiologi di RS PKU Muhammadiyah Gamping Yogyakarta.

[12] Wong,Alifia W,. (2017). Analisis Perubahan Hemoglobin Pada Pasien Gangguan Ginjal Kronik (Ggk) Yang Menjalani Hemodialisis Selama 3 Bulan Di Rumah Sakit Perguruan Tinggi Negeri (Rsptn) Universitas Hasanuddin (Unhas) Makassar. Skripsi. Makassar. Universitas Hasanuddin Makassar. 